\title{
Personality Factors, Academic Emphasis, and Students- Lecturers' Relationship as Determinants of Undergraduates' Academic Achievement Goal Orientation: The Nigeria Experience.
}

\author{
${ }^{1}$ Ayodele, Kolawoleolanrewaju, ${ }^{2}$ Aladenusi, Oluwakemi, ${ }^{3}$ Akinlana, Temidayo \\ ${ }^{I}$ Office of Institutional Effectiveness Babcock University Ilishan, Ilishan-Remo \\ Ogun State, Nigeria. \\ ${ }^{2}$ School of Education, Dept. of Psychology, Federal College of Education (tech.), Akoka, Lagos State \\ ${ }^{3}$ OlabisiOnabanjo University Faculty of Education, Ago Iwoye, Ogun State.
}

\begin{abstract}
The study examined the interrelationships among personality factors, academic emphasis, studentslecturers relationship and academic achievement orientation of Nigerian undergraduates in Southwest Nigeria. Three thousand four hundred and eighty-nine (3489) randomly selected undergraduates took part in the study. Four (4) valid and reliable instruments were used for data collection. These instruments are: The Big Five Inventory by John and Srivastava (1999); Achievement Goals Orientation Scale by Was (2006); Academic Achievement Motivation Scale by Vallerandet al., (1992); and Student-Instructor Relationship Scale by Creasey, Jarvis, \&Knapcik (2009). Data analysis involved mean and standard deviation as descriptive statistics and multiple regression statistical analysis as inferential statistics. The results showed that the independent variables (personality factors, students-lecturers' relationship, \& academic emphasis) accounted for $35.9 \%$ of the total variance in undergraduates' academic achievement goal $\left(R=.404 ;\right.$ Adj. $\left.R^{2}=.359 ; F_{(1,3486)}=19.507 ; P<.05\right)$. Also, students' personality was found to significantly influenced by academic emphasis of the school (Adj. $R^{2}=$ $\left..226, F_{(6,3482)}=18726\right)$ while students-lecturers' relationship $\left(\right.$ Adj. $\left.R^{2}=.311, F_{(7,3481)}=21.788\right)$ and undergraduates' achievement goal orientation (Adj. $\left.R^{2}=.103, F_{(6,3483)}=16.174\right)$ were found to be influenced by personality factors. Findings of the study further indicated a significant influence of academic emphasis on undergraduates' achievement goal (Adj. $\left.R^{2}=.177, F_{(1,3487)}=12.963, P<.05\right)$, while students-lecturers' relationship was also found to influence students' achievement goal orientation significantly (Adj. $R^{2}=.159, F$ $(3,3485)=16.174, P<.05)$. The study concluded that the accurate prediction of undergraduates' academic achievement through personality factors, students-lecturers relationships, and academic emphasis has important implications for education, and not just at the higher institution's level
\end{abstract}

Keywords: Personality factors; academic emphasis; students-lecturers relationship; academic achievement orientation; Nigerian undergraduates.

\section{Introduction}

Over the years, academic achievements become extremely important to all stake holders in education and for the students in particular the stigmatization of being called a "failure". As noted by Othman \&Leng (2011) students' academic achievement can be related to their choices of subject or streaming and even their secondary school, university and scholarship. Therefore, an important indicator of academic success at university level today is the academic achievement of students. Coetzee (2011) affirms that students with higher levels of achievement at university are more likely to obtain good employment and salaries.

However, there has been variation in children's cognitive abilities and skills which explains gap in academic achievement among students of varied racial and ethnic backgrounds (Hansen, Liu, \&Kučera, 2010). Yet such abilities and skills may not fully explain their academic achievement (Schunk\& Zimmerman, 2007; Graham \&Hudley, 2005), suggesting that there are other pertinent factors at play in determining children's academic achievement. It is in this context that the non-cognitive correlates of academic achievement, such as academic self-concept and academic motivation, have been found to play a pivotal role in children's school achievement (Akinlana, 2012; Areepattamannil, Freeman, \& Klinger, 2011; Becker, McElvany, \&Kortenbruck, 2010).

Though, there is a growing body of research devoted to the study of personality factors, academic emphasis, and students-lecturers relationship of students across levels of education (Akinlana, 2012; Areepattamannil, 2011; Adeyemo\&Torubeli 2008), no study to date has examined the interrelationships among personality factors, academic emphasis, students-lecturers relationship and academic achievement orientation of Nigerian undergraduates. 
Prior research studies have focused mostly on academic achievement among young students, and provides no clear and consistent evidence regarding the extent to which personality factors relate to academic emphasis, students-teachers' relationship and achievement. The current study addresses these gaps by examining the relationship among the variables as homogenous whole among undergraduates in Nigeria.

\section{Personality Factors and Academic Achievement}

Camilus (2011) citing Denga (2002) sees personality of an individual as a collection of emotional, thought and behavioural patterns unique to a person that is consistent overtime. It can also include an individual's thoughts, behaviour, feelings, emotions, attitudes, physique adjustment, unique learning history response patterns, habits and general poise.The relation between personality and academic achievement has been one of the controversial issues. A study by O'Connor \&Paunonen (2007) found that personality predictors can account for variance in academic performance beyond that accounted for by measures of cognitive ability. In a meta-analysis study by Ghapanchi, Khajavy, Asadpour (2011) and O'Connor \&Paunonen (2007), it has been suggested that behavioral tendencies reflected in personality traits affect certain habits that can have an influence on academic success.

The relationship between cognitive ability and academic success is often weaker than expected in samples of university students, compared to samples of elementary and secondary school students (O'Connor \&Paunonen, 2007). The only explanation for this setback in predictive power is restriction of range in the intelligence scores of students enrolled in post-secondary programs (Furnham et al., 2003).

Ackerman et al. (2001) noted that the criterion of academic achievement tends to shift over time, from factors that favor cognitive abilities (e.g., critical thinking) to factors that favor personality or motivational variables (e.g., domain knowledge). In addition, universities seem to be placing a greater emphasis on continuous assessment methods (e.g., attendance, class participation), and personality traits might be especially relevant for predicting such criteria. Taken together, the three broad justifications outlined above provide a strong impetus for examining personality variables as predictors of post-secondary academic performance (O’Connor \&Paunonen, 2007).

\section{Academic Emphasis and Academic Achievement}

Academic emphasis (otherwise known as academic press) entails teacher's ability to accentuate more on academic tasks than other tasks such as social and affective. It is the extent at which a school is driven by a quest for academic excellence - a press for academic achievement (Hoy et al., 2006; Hoy \&Miskel, 2005). This drive for excellence includes a school's display of high, achievable goals set for all students; a learning environment that is orderly and serious; students who are motivated to work hard; and students who respect academic achievement (Hoy et al., 2006; Hoy \&Miskel, 2005).

Academic emphasis is a reflection of a school's seriousness about its core purpose. Although it should go without saying that all schools have an academic emphasis, this is not in fact the case. Some schools show, through their organisational attitudes and actions, that academic achievement is not highly valued, while others consistently reinforce the importance of academic.

Weinstein \&Mignano, 2007) affirm that academic learning time for students is essential because the time students spend successfully and actively engaged in an academic task relates positively to student learning. Students have also been reported by Woolfolk, (2010) to spend only one-third of their hours on academic learning. Effective teachers make sure students are "actively engaged in worthwhile, appropriate learning activities" to ensure students' time in school is productive (Fahy, Wu, \& Hoy, 2010; Woolfolk, 2010). Although teacher trust, teacher sense of efficacy and teacher academic emphasis make sense as individual variables (Fahy, Wu, \& Hoy, 2010).

In a study of five hundred and eighty-eight participants among secondary school students, Akinlana (2012) found that academic optimism and emphasis were good predictors of student's academic performance. Studies that used motivational perspectives, such as achievement motivation, achievement goal, and academic intrinsic motivation, have also found that intrinsically motivated students tend to have higher academic achievement (Gottfried, Marcoulides, Gottfried, Oliver, \& Guerin, 2007), higher intellectual performance (Gottfried \& Gottfried, 2004), less academic anxiety (Gottfried, 1990), and mastery-oriented coping with failure (Dweck, 1975). Numerous studies have documented the effects of extrinsic motivation on learning outcomes as well. Students who are extrinsically motivated are more likely to have lower academic achievement (Becker et al., 2010; Lepper, Corpus, \&Iyengar, 2005), and to engage in surface learning (Biggs, 1991).

According to Gesinde (2000), academic motivation could be seen as self-determination to succeed in academic work. He posits that the urge to achieve varies from one individual to the other, while for some individuals, the need for achievement is very high and for others it may be very low. What could be responsible for the variation could be the fact that academic motivation is believed to be developed during socialisation processes and learning experiences (Ajayi, Lawani, \&Salomi, 2012). 


\section{Student-Teacher Relationships and Academic Achievement}

Research over the past century has focused on how students learn and the variables that significantly impact their learning. Teaching and learning process demands a large proportion of time being devoted to personal interaction between the teachers and the students. Positive teacher-student relationships are believed to be necessary for effective teaching and learning to take place (Adeyele\&Yusuff 2012; McInerney\&McInerney, 2006; Sztejnberg, den Brok, \&Hurek, 2004). Effective teachers are those who, in addition to being skilled at teaching, are attuned to the human dimension of classroom life and can foster positive relationships with their students (Good \&Brophy, 2000; Larrivee, 2005).

Research has proved that the student-teacher relationship plays a significant role in students' success both in academics and social/emotional development. Ray, Henson, Schotterlkorbm, Brown, \&Muro (2008) emphasized in their article the importance of student-teacher relationship by listing many studies that indicate the influence of a positive relationship between a teacher and students on the students' academic achievement. In addition, difficulties in student-teacher relationships seemed to affect both the students' academic success and social/emotional development negatively. Adeyele\&Yusuff (2012) affirmed that student's CGPA raises as rapport between student and lecturer gets better.

Lee (2007) found that the trust developed between the student and the teacher can contribute to students' academic performance. Noddings (1992) cited by Knoell (2012) shared that students make learning a higher priority and thus work harder for teachers whom they care about and perceive as also valuing their learning. Lyubomirsky, King, and Diener (2005) noted "numerous successful outcomes, as well as behaviors paralleling success" (p. 803); and Birch and Ladd (1996 \& 1998) reported that the student-teacher relationship can influence students' future paths toward academic success and was positively linked with children's academic performance. Lastly, Miller (2000) found that the student-teacher relationship play an important role in helping reduce the chances of future bad outcomes, i.e. dropping out of school.

Studies of Sztejnberg et al., (2004); Pianta, (1999); and Howes, Hamilton, \& Matheson, (1994) revealed that teacher-student relationships greatly influence a student's ability to adjust to school, to do well at school, and to relate to peers. Teacher-students relationships have an impact on classroom management and affect learning progress (Klem and Connell, 2004; Sztejnberg et al., 2004). In providing a positive environment and strengthening the relationship with the students, meaningful and positive student-teacher relationships have proved to be a significant impact on students' success both academically and interpersonally (Pianta\&Stuhlman, 2004; Burchinal, Peisner-Feinberg, Pianta, \&Howes, 2002).

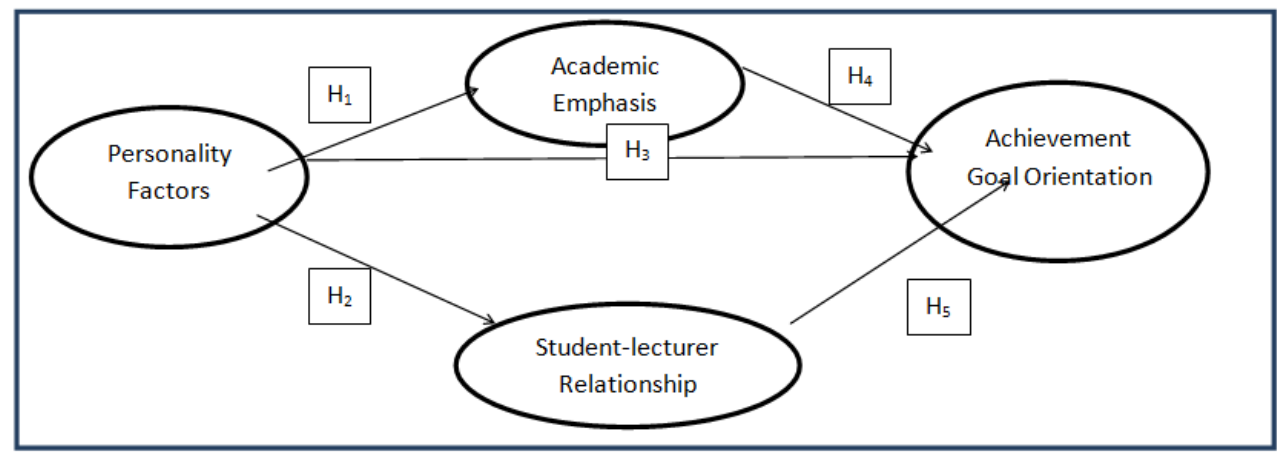

Figure 1: Research Model for the Study

\section{Research Hypotheses}

Based on the above discussion and research model, the following hypotheses were formulated and tested at 0.05 significant level:

\section{Main Hypothesis}

1. There is no significant composite contribution of personality factors, students-lecturers relationships, and academic emphasis on undergraduates' academic achievement.

\section{Sub-hypotheses}

1. Personality factors will not be significantly influencedby academic emphasis.

2. Personality factors will not significantly influence students-lecturers relationships.

3. Personality factors will not significantly influence undergraduates' achievement goal orientation.

4. Academic emphasis will not significantly influence undergraduates' achievement goal orientation.

5. Students-lecturers relationships will not significantly influence undergraduates' achievement goal orientation. 


\section{Methodology}

Design: This study adopted a survey research design of an ex-post-facto type. This is so, because the researchers were only interested in determining the influence of the independent variables on the dependent variable.

Population/Sample Size: There are six states in the south-west Nigeria. A multi-stage sampling procedure was used to select the states and the universities that participated in the study. Multi-stage sampling technique was chosen because it is a stage-by-stage system of sampling method. The states were first selected through simple random sampling technique, in which three states were selected out of the six states for the study. From each of the states, three universities were purposively selected (one federal, one private and one state). In all nine universities were selected.The sample for this study consisted of 3,600 undergraduates.

Sampling Procedure: Four hundred questionnaires were given out to each of the participatinguniversity. Some proctors were made use of in this quantitative study in the administration of the questionnaires. Out of the 3,600 questionnaires sent out, 111 were not properly filled or missed out in the course of retrieval, which invalidate them for the purpose of the study. It can however, be said that there was $(3,489) 96.9 \%$ success of questionnaire administration.

Research Instruments: Four major instruments were used for this study. These were used to obtain information concerning the variables of the study.

1. The Big Five Inventory (BFI):The BFI is a multi-items inventory of 50 items developed by John and Srivastava (1999), sub-divided into 5 traits namely Neuroticism, Extraversion, Openness to experience, Agreeableness and Consciousness. The items included "Make plans and stick to them," "Have a vivid imagination," Respondents indicate how they generally feel by rating the degree of their feelings on a sixpoint scale where 1="extremely disagreed", 2="very disagreed", 3="somewhat disagreed", 4="somewhat agreed", $5=$ "very agreed", and $6=$ "extremely agreed". The BFI is reported to have overall alpha of 0.84 while the neuroticism scale $=.82$; extraversion $=0.86$; openness to experience $=0.82$; agreeableness $=0.86$ and consciousness $=0.87$. BFI has been used among Nigerian subjects and reported valid and not culturally biased (Ayodele\&Nwosu, 2011; Idowu\&Oledikwa, 2003)

2. Achievement Goals Orientation Scale (AGOS):AGOS was developed by Was (2006) designed to measure the four types of students' achievement goal orientations (i.e., mastery, performance approach, performance avoidant, and work avoidant). It is a 33 items based on a 6-point Likert Scale ranging from (1) very untrue to (6) very true measuring different goal orientations. Examples of the items of the AGOS are "I challenge myself with goals for a test based on my past exam results"; "I am more concerned with improving from week to week than I am in doing better than others in the class". The reliability index of the questionnaire ranges from values of .64 to .81 Cronbach's Alpha. However, the instrument was re-validated has a validity coefficient of .89

3. Academic Achievement Motivation Scale:Academic Achievement Motivation was measured using the Academic Achievement Motivation Scale (AMS; Vallerandet al., 1992). The AMS consists of 28 items assessed on a 7-point scale, in which students responded to the question stem "Why are you going to college?" There are seven subscales on the AMS: A motivation (AMOT), External Regulation (EXTR), Introjected Regulation (INTR), Identified Regulation (IDTR), Intrinsic Motivation to Know (IMTK), Intrinsic Motivation to Experience Stimulation (IMES) and Intrinsic Motivation to Accomplish (IMTA). The items are rated on a scale, ranging from one (does not correspond at all) to seven (corresponds exactly). Each subscale consists of four items each; thus subscale scores can range from four to twenty-eight. A high score on a subscale indicates high endorsement of that particular academic motivation. It has been shown that the three types of intrinsic motivation are significantly and positively correlated with each other 0.67 , 0.62 and 0.58 , while the three (3) types of extrinsic motivation are significantly and positively intercorrelated 0.50, 0.49 and 0.45 (Cokley, 2000). AMS has been used among Nigerian subjects and reported valid and not culturally biased (Ebonhor, 2012; Ayodele, 2008)

4. Student-Instructor Relationship Scale (SIRS): SIRS constructed by Creasey, Jarvis, \&Knapcik (2009) was adopted for this study. SIRS is a 36- item instrument in which respondents consider different relationship qualities with instructors on a 7-point, Likert scale ( 1 = Disagree Strongly; 7 = Agree Strongly). 19 out of the 36 items were used in this study. The first factor contained eleven items (e.g., "It's not difficult for me to feel connected to this instructor"; "I feel comfortable sharing my thoughts with this instructor") designated as the Instructor Connectedness dimension; higher scores denoted stronger feelings of connectedness and low scores on this scale communicated avoidance or a tendency to eschew a close relationship with the instructor. The second factor contained eight items (e.g., "I am nervous around this instructor"; "I worry that I won't measure up to this instructor's standards") labeled the instructor anxiety 
dimension. Higher scores reflected a generalized anxiety regarding a relationship with the instructor, whereas lower scores reflect less threatening perceptions of this affiliation. The connectedness subscale has a correlation alpha of .69 while the Anxiety subscale was .66. The aggregated internal consistency for both subscales was .89 (Creasey, Jarvis, \&Knapcik, 2009).

Data Analysis: The data collected from the respondents were subjected to statistical analysis of multiple regression statistical analysis.

\section{Results}

Table 1: Model summary of the multiple regression analysis of the contribution of personality factors, student-lecturer relationship, and academic emphasis on undergraduates' academic achievement goal

\begin{tabular}{|c|l|l|l|l|l|l|l|l|l|}
\hline & $\mathrm{R}$ & $\mathrm{R}^{2}$ & Adj. $\mathrm{R}^{2}$ & $\mathrm{SE}$ & \multicolumn{5}{c|}{ Change Statistics } \\
\hline Model & & & & & $\begin{array}{c}\mathrm{F} \\
\text { Change }\end{array}$ & $\begin{array}{l}\mathrm{F} \\
\text { Change }\end{array}$ & $\mathrm{d}$ f 1 & $\mathrm{d} \mathrm{f} \mathrm{2}$ & $\begin{array}{l}\text { Sig. F } \\
\text { Change }\end{array}$ \\
\hline $\begin{array}{l}\text { Predictor } \\
\text { Variables }\end{array}$ & .404 & .376 & .359 & 10.901 & .359 & 19.507 & 3 & 3485 & .000 \\
\hline
\end{tabular}

a. Predictions: (Constant), Personality factors, students-lecturers' relationship, \& academic emphasis

b. Dependant Variable: Undergraduates' Academic Achievement Goal

Table 1 show that all the independent variables (personality factors, students-lecturers' relationship, \& academic emphasis) put together yielded a coefficient of multiple regression $\mathrm{R}$ (adjusted) of .376 , and a multiple $\mathrm{R}^{2}$ (adjusted) of .359. This implies that $35.9 \%$ of the variance in undergraduates' academic achievement goal is accounted for by the combination of the three independent variables. The table reveals that the analysis of the variance of the multiple regression data produces an F-ratio value significant at 0.05 level $\left(\mathrm{F}_{(3,3485)}=19.507 ; \mathrm{P}<0.05\right)$. The finding implies that undergraduates' academic achievement goal will be significantly affected by personality factors, students-lecturers relationships, and academic emphasis.

Table 2: Model summary of the step-wise regression of the composite contribution ofpersonality factors, student-lecturer relationship, and academic emphasis on undergraduates' academic achievement goal

\begin{tabular}{|l|l|l|l|l|l|l|l|l|l|}
\hline \multicolumn{1}{|c|}{} & $\mathrm{R}$ & $\mathrm{R}^{2}$ & $\mathrm{Adj} . \mathrm{R}^{2}$ & $\mathrm{SE}$ & \multicolumn{5}{c|}{ Change Statistics } \\
\hline Model & & & & & $\begin{array}{c}\mathrm{R}^{2} \\
\text { Change }\end{array}$ & $\begin{array}{c}\mathrm{F} \\
\text { Change }\end{array}$ & $\mathrm{d}$ f 1 & $\begin{array}{l}\text { Sig. F } \\
\text { d f } 2\end{array}$ \\
\hline Personality factors & .201 & .180 & .180 & 23.106 & .180 & 9.818 & 1 & 3487 & .000 \\
\hline $\begin{array}{l}\text { Personality factors, } \\
\text { students-lecturers' } \\
\text { relationship }\end{array}$ & .324 & .308 & .305 & 19.097 & .125 & 15.328 & 1 & 3486 & .000 \\
\hline $\begin{array}{l}\text { Personality factors, } \\
\text { students-lecturers' } \\
\text { relationship and } \\
\text { academic emphasis }\end{array}$ & .404 & .376 & .359 & 10.901 & .054 & 19.507 & 1 & 3485 & .000 \\
\hline
\end{tabular}

a. Predictors: (Constant), Personality factors

b. Predictors: (Constant),Personality factors, students-lecturers' relationship

c. Predictors: (Constant),Personality factors, students-lecturers' relationship, academic emphasis

The result in Table 2 showed that when personality factors was entered into the regression model due to the strength of its relationship with undergraduates' academic achievement goal, there was a significant prediction $\left(\mathrm{R}=.201 ;\right.$ Adj. $\left.\mathrm{R}^{2}=.180 ; \mathrm{F}_{(1,3487)}=9.818 ; \mathrm{P}<.05\right)$. This showed that the $18 \%$ contribution of the variance in undergraduates' academic achievement Goal is accounted for by personality factors.

However, when students-lecturers' relationship entered the model as the second predictor variable, there was a significant prediction of undergraduates' academic achievement goal $\left(\mathrm{R}=.324\right.$; Adj. $\mathrm{R}^{2}=.308$; $\left.\mathrm{F}_{(1,3486)}=15.328 ; \mathrm{P}<.05\right)$. This means that personality factors, along with students-lecturers' relationship, accounted for $30.8 \%$ of the variance in the undergraduates' academic achievement goal.Students-lecturers' relationship, therefore accounted for an additional $12.5 \%$ of the variance in the undergraduates' academic achievement goal.

Also, when academic emphasis was entered into the model as the third predictor variable, there was a significant prediction of undergraduates' academic achievement goal $\left(\mathrm{R}=.404 ;\right.$ Adj. $\mathrm{R}^{2}=.359 ; \mathrm{F}_{(1,3486)}=$ 19.507; $\mathrm{P}<.05)$. This means that academic emphasis, along with personality factors and students-lecturers' relationship, accounted for $35.9 \%$ of the variance in undergraduates' academic achievement goal. In essence, academic emphasis accounted for an additional $5.4 \%$ of the variance in undergraduates' academic achievement goal. 
Table 3: Summary of regression analysis of theindependent variables on the dependent variable as highlighted in the hypotheses

\begin{tabular}{|c|c|c|c|c|c|c|}
\hline $\mathrm{S} / \mathrm{N}$ & Variable & $\mathrm{R}^{2}$ & $\mathrm{Df}$ & f-value & Sig. & Decision \\
\hline 1 & Personality factors and academic emphasis & .226 & $6 / 3482$ & 18.726 & .000 & Significant \\
\hline 2 & $\begin{array}{l}\text { Personality factors and students-lecturers } \\
\text { relationships }\end{array}$ & .311 & $7 / 3481$ & 21.788 & .013 & Significant \\
\hline 3 & $\begin{array}{l}\text { Personality factors andachievement goal } \\
\text { orientation }\end{array}$ & .103 & $6 / 3483$ & 15.406 & .000 & Significant \\
\hline 4 & $\begin{array}{l}\text { Academic emphasis andachievement goal } \\
\text { orientation }\end{array}$ & .177 & $1 / 3487$ & 12.963 & .122 & Significant \\
\hline 5 & $\begin{array}{l}\text { Students-lecturers relationships and } \\
\text { achievement goal orientation }\end{array}$ & 159 & $3 / 3485$ & 16.174 & .034 & Significant \\
\hline
\end{tabular}

The regression procedure was used to test the significance and form of the main influence as indicated in the sub-hypotheses $1,2,3,4$, and 5. Personality factors was found to be significantly influencedby academic emphasis of the school(Adj. $\left.\mathrm{R}^{2}=.226, \mathrm{~F}_{(6,3482)}=18726\right)$, personality factors was found to influence studentslecturers' relationship (Adj. $\mathrm{R}^{2}=.311, \mathrm{~F}_{(7,3481)}=21.788$ ) and undergraduates' achievement goal orientation (Adj. $\left.\mathrm{R}^{2}=.103, \mathrm{~F}_{(6,3483)}=16.174\right)$. The results as shown in Table 3 above also indicate significant influence of academic emphasis on undergraduates' achievement goal(Adj. $\left.\mathrm{R}^{2}=.177, \mathrm{~F}_{(1,3487)}=12.963, \mathrm{P}<.05\right)$. Studentslecturers' relationshipwas also found to influence students' achievement goal orientation significantly $\left(\right.$ Adj. $R^{2}=$ $.159, \mathrm{~F}(3,3485)=16.174, \mathrm{P}<.05)$.

\section{Discussion of Findings}

The findings of the main hypothesis indicated that personality factors, students-lecturers relationships, and academic emphasis combined to predict undergraduates' academic achievement goal orientation.This showed that $35.9 \%$ of the variance in undergraduates' academic achievement goal is accounted for by the combination of the three independent variables. The empirical result shows that undergraduates' academic achievement goal will be significantly affected by personality factors, students-lecturers relationships, and academic emphasis of the school.The implication is that in an African country like Nigeria, with a tight mindset on certification, tight social framework, and poor service quality in academia, maypose a serious challenge on students' academic excellence.It is also assumed that excellent service quality performance in education is one of the key factors in building niche and harnessing all necessary factors together not just to ensure academic excellence of the students but having competitive edge that promotes development nationally and globally.

This findings therefore lend credence to past findings which established that students' cognitive abilities and skills cannot not fully explain the gap in their academic achievement (Schunk\& Zimmerman, 2007; Graham \&Hudley, 2005), and that other pertinent factors are at play in determining students' academic achievement (Akinlana, 2012; Areepattamannil, Freeman, \& Klinger, 2011; Becker, McElvany, \&Kortenbruck, 2010).

Students' personality was found to be significantly influencedby academic emphasis of the school(Adj. $\left.\mathrm{R}^{2}=.226, \mathrm{~F}_{(6,3482)}=18726\right)$. This result may be as a result of the nature-nurture development of man, and no matter who one is, his or her environment have direct influence on him/her. This result corroborates the studies of Ackerman et al. (2001) that the criterion of academic achievement over time has shifted from factors inherent in cognitive abilities to thosethat favour personality factors. Both cognition and personality factors can be influenced positively and negatively by the school academic emphasis which is a strong impetus for postsecondary academic performance. This is also supported by Akinlana, (2012), O'Connor \&Paunonen(2007), Hoy et al. (2006), and Hoy \&Miskel, (2005) that the drive for excellence includes a school's display of high, achievable goals set for all students; a learning environment that is orderly and serious; students who are motivated to work hard; and students who respect academic achievement.

Students-lecturers' relationship (Adj. $\left.\mathrm{R}^{2}=.311, \mathrm{~F}_{(7,3481)}=21.788\right)$ and undergraduates' achievement goal orientation (Adj. $\mathrm{R}^{2}=.103, \mathrm{~F}_{(6,3483)}=16.174$ )were found to be influenced by personality factors. It can be deduced that personal relationships of the students with their teachers will afford them internal rewards, give meaning to their academic work, and motivate them to learn. Also, teacher-student relationships encompass so many features of individuals which include personality type, social skills; as well as the perceptions each individual holds of their relational partner and the relationship itself.

The implication for this finding is in line with Fowler \& Christakis(2008) and (Uzzi, 1997) that individuals develop relationships for many reasons, including to fill emotional needs and to gain access to resources. This relationship to a great extent has been shown to influence academic outcomes such as academic performance, development, and persistence (Rizzuto, LeDoux, \&Hatala, 2009), as well as health outcomes (Valente et al., 2007, 2009). This study therefore, lend credence to the findings of Roorda et al. (2011)that the 
affective quality of the teacher-student relationship is an important factor in their school engagement, wellbeing, and academic success.

The other aspect of the findings indicated significant influence of academic emphasis on undergraduates' achievement goal (Adj. $\mathrm{R}^{2}=.177, \mathrm{~F}_{(1,3487)}=12.963, \mathrm{P}<.05$ ), whilestudents-lecturers' relationship was also found to influence students' achievement goal orientation significantly (Adj. $\mathrm{R}^{2}=.159, \mathrm{~F}$ $(3,3485)=16.174, \mathrm{P}<.05)$. Therefore, the drive for excellence by schools is factor to be reckoned with (Akinlana, 2012, O'Connor \&Paunonen,2006), while relationship (social interaction) has been found to evoke certain affective responses within individuals (Adenuga\&Ayodele, 2010; Azeez, 2007). Also, this finding lend credence from the findings that school tones and the interrelationship among its components provide the physical and social support needed for each individual's physical and mental well-being (Tschan, Semmer\& Inversion, 2004; Myers \&Diener, 1995).

\section{Conclusion}

This study hasshown that personality factors, students-lecturers relationships, and academic emphasis significantly influence undergraduates' academic achievement. The accurate prediction of undergraduates' academic achievementthrough personality factors, students-lecturers relationships, and academic emphasis has important implications for education, and not just at the higher institution's level.

\section{Limitation of the Study}

Though, the study sheds some valuable insights into the crucial role played by personality factors, students-lecturers relationships, and academic emphasis in the learning process especially on undergraduates' academic achievement. Firstly, this study is limited by using convenience sampling. Future research could extend these findings by including other variables such as individual differences, thinking styles, socioeconomic status or self-efficacy in explaining students'academic achievement. The findings can be used as a reference for future studies. Secondly, future research could be expanded in scope, method of data collection and analysis.

[1] Ackerman, P. L., Bowen, K. R., Beier, M. E., \&Kanfer, R. (2001).Determinants of individual differences and genderdifferences in knowledge.Journal of Educational Psychology, 93, 797-825.

[2] Adenuga, A \&Ayodele, K. (2010). Psychological Dispositions Associated with Adolescents' Social Interaction: An Empirical Assessment in Nigeria Context. International Journal of Research in Education, 2(8), 80-88

[3] Adeyemo, D. A., \&Torubeli, V.A. (2008). Self-efficacy, self-concept and peers influence as correlates of achievement among secondary school students in transition. Pakistan Journal of Social Sciences, 5(1), 10-16.

[4] Ajayi, K. O., Lawani, A. O., \&Salomi, M. O. (2012). The influences of self-concept and academic motivation on students' attitude to Mathematics in selected secondary schools in Ogun State, Nigeria.European Journal of Scientific Research 67(3), 444-455

[5] Areepattamannil, S., Freeman, J. G., \& Klinger, D. A. (2011).Intrinsic motivation, extrinsic motivation, and academic achievement among Indian adolescents in Canada and India.Social Psychology of Education. Advance online publication. doi:10.1007/s11218011-9155-1

[6] Becker, M., Mcelvany, N., \&Kortenbruck, M. (2010). Intrinsic and extrinsic reading motivation as predictors of reading literacy: A longitudinal study. Journal of Educational Psychology, 102, 773-785. doi:10.1037/a0020084

[7] Birch, S. H., Ladd, G. W. (1997).The teacher-child relationship and children's early school adjustment. Journal of School Psychology, 35, 61-79.

[8] Burchinal, M. R., Peisner-Feinberg, E., Pianta, R. C., Howes, C. (2002). Development of academic skills from preschool through second grade: Family and classroom predictors of developmental trajectories. Journal of School Psychology, 40, 415-436.

[9] Camilus B. B. (2011). Student's Personality Characteristics and their Academic Performance in Agricultural Science in Secondary Schools in Uyo Municipality, AkwaIbom State, Nigeria. Journal of Education and Leadership Development, 3, 36-53

[10] Creasey, G.; Jarvis, P.; Knapcik, E. (2009).A measure to assess student-instructor relationships.International Journal for the Scholarship of Teaching and Learning, 3(2); 1-10. Retrieved from http://www.georgiasouthern.edu/ijsotl

[11] Fowler, J. H., and N. A. Christakis. (2008). Dynamic spread of happiness in a large social network:Longitudinal analysis over 20 years in the Framingham Heart Study. British Medical Journal,337, 1-9.

[12] Furnham, A., Chamorro-Premuzic, T., \& McDougall, F. (2003).Personality, cognitive ability, and beliefs aboutintelligence as predictors of academic performance.Learning and Individual Differences, 14, 49-66.

[13] Ghapanchi, Z; Khajavy, G; Asadpour, S. (2011). L2 motivation and personality as predictors of the second language proficiency: role of the big five traits and 12 motivational self-system. Canadian Social Science, 7(6), 148-155

[14] Good, T., \&Brophy, J. (2000). Looking In Classrooms (8th ed.). New York: Longman.

[15] Graham, S., \&Hudley, C. (2005).Race and ethnicity in the study of motivation and competence.In A. Elliot \& C. Dweck (Eds.), Handbook of competence and motivation (pp. 392-414). New York, NY: Guilford.

[16] Hansen, J., Liu, X., \&Kučera, M. (2010).Educational attainment of children of immigrants: Evidence from two cohorts of American youths. Retrieved from http://economics.concordia.ca on June 8, 2012.

[17] Hoy, W. K; Tarter, C. J. \&Woolfolk Hoy, A. (2006a). Academic optimism of schools: A fore for student achievement. American Educational Research Journal,43(3), 425-446.

[18] Larrivee, B. (2005). Authentic Classroom Management: Creating a learning community and building reflective practice (2nd ed.). Boston, USA: PearsonEducation, Inc.

[19] Lee, J. Q., McInerney, D. M., Liem, G. A., \&Ortiga, Y. P. (2010).The relationship between future goals and achievement goal orientations.Contemporary Educational Psychology, 35, 264-279. doi:10.1016/j.cedpsych.2010.04.004

[20] Lee, S. J. (2007). The relations between the student-teacher trust relationship and school success in the case of Korean middle schools. Educational Studies, 33(2), 209-216. 
[21] Lyubomirsky, S., King, L., \&Diener, E. (2005). The benefits of frequent positive affect: Does happiness lead to success? Psychological Bulletin, 131, 803-855.

[22] Leitão, N. \& Waugh, R. (2007).Teachers' Views of Teacher-Student Relationships in the Primary School.A paper presented at the 37th Annual International Educational Research Conference, held by the Australian Association for Research in Education at Fremantle, Western Australia.

[23] Knoell, C. M. (2012). The role of the student-teacher relationship in the lives of fifth graders: A mixed methods analysis. A Ph.D dissertation of the Graduate College at the University of Nebraska.

[24] McInerney, D., \&McInerney, V. (2006).Educational Psychology: Constructing Learning (4th ed.). Frenchs Forest, NSW: Pearson Education Australia.

[25] Miller, S. R. (2000). Falling off track: How teacher-student relationships predict early high school failure rates.Paper presented at the annual meeting of the American Educational Research Association, New Orleans, LA. (ERIC Document Reproduction Service No. 441907)

[26] O’Connor, M.C. and Paunonen, S.V. (2007). Big Five personality predictors of post-secondaryacademic performance.Personality and Individual Differences 43, 971-990

[27] Othman, N. \&Leng, K. B (2011).The relationship between self-concept, intrinsic motivation, self-determination and academic achievement among Chinese primary school students. International Journal of Psychological Studies, 3(1), 90-98. doi:10.5539/ijps.v3n1p90

[28] Pianta, R., Stuhlman, M. W. (2004). Teacher-child relationship and children's success in the first years of school. School Psychology Review, 33, 444-459.

[29] Pianta, R. (1999). Enhancing Relationships Between Children and Teachers (1st ed.). Washington, DC: American Psychological Association.

[30] Ray, D. C., Henson, R. K., Schottelkorb, A. A., Brown, A. G., Muro, J. (2008). Effect of short- and long-term play therapy services on teacher-child relationship stress. Psychology in Schools, 45(10), 994-1009.

[31] Rizzuto, T. E., LeDoux, J., \&Hatala, J. P. (2009). It's not just what you know, it's who you know:Testing a model of the relative importance of social networks to academic performance, SocialPsychology of Education, 12, 175-189. doi:10.1007/s11218-0089080-0

[32] Roorda, D. L., Koomen, H. M. Y., Spilt, J. L., \&Oort, F. J. (2011). The influence of affective teacher-student relationships on students' school engagement and achievement: A meta-analytic approach. In revision for publication in Review of Educational Research.

[33] Sztejnberg, A., den Brok, P., \&Hurek, J. (2004).Preferred Teacher-Student Interpersonal Behaviour: Differences Between Polish Primary and Higher Education Students' Perceptions.Journal of Classroom Interaction, 39(2), 32-40.

[34] Schunk, D. H., \& Zimmerman, B. J. (2007). Influencing children's self-efficacy and self-regulation of reading and writing through modelling. Reading \& Writing Quarterly, 23, 7-25. doi:10.1080/10573560600837578.

[35] Uzzi, B. (1997). Networks and the paradox of embeddedness.Administrative Science Quarterly, 42(1),35-67.

[36] Valente, T. W., Fujimoto, K., Chou, C., \&Spruijt-Metz, D. (2009) Adolescent affiliations and adiposity: A social network analysis of friendships and obesity. Journal of Adolescent Health, 45(2), 202-204. doi:10.1016/j.jadohealth.2009.01.007 